\title{
Noticing Breaches with Nonpolar Interrogatives: Estonian \& Kes (“Who”) Ascribing Responsibility for Problematic Conduct
}

Kirsi Laanesoo and Leelo Keevallik

The self-archived postprint version of this journal article is available at Linköping University Institutional Repository (DiVA):

http:/ / urn.kb.se/ resolve?urn=urn:nbn:se:liu:diva- 140153

N.B.: When citing this work, cite the original publication.

This is an electronic version of an article published in:

Laanesoo, K., Keevallik, L., (2017), Noticing Breaches with Nonpolar Interrogatives: Estonian Ke ("Who") Ascribing Responsibility for Problematic Conduct, Research on Language and Social Interaction, 50(3), 286-306. https:// doi.org/ 10.1080/ 08351813.2017.1340721

Original publication available at:

https:/ / doi.org/ 10.1080/08351813.2017.1340721

Copyright: Taylor \& Francis (Routledge) (SSH Titles)

http:/ / www.routledge.com/ 
Title of the article:

Noticing breaches with non-polar interrogatives: Estonian kes 'who' ascribing responsibility for problematic conduct

Authors:

Kirsi Laanesoo, University of Tartu, Estonia

Leelo Keevallik, Linköping University, Sweden
Corresponding author:

Institutional address:

Co-author:

E-mail address:

Title for running head:

Kirsi Laanesoo

Institute of Estonian and General Linguistics

University of Tartu

Jakobi 2

51014 Tartu

Estonia

Phone number:

+37251933102

E-mail address:

kirsi.laanesoo@ut.ee

Leelo Keevallik

leelo.keevallik@liu.se

Kes ascribing responsibility for problematic conduct 


\begin{abstract}
This paper targets action formation in multimodal sequences. It shows how non-polar interrogatives in Estonian are used for noticing breaches in others' embodied conduct, focusing on kes 'who'-interrogatives. In contrast to information questions with kes, a "noticing of a breach" does not seek an informative answer, which would be an identification of the grammatical actor of the action depicted in the interrogative. The actor is instead the addressee of the turn, often called by name, and thus clear to everyone present. These “rhetorical” kes-interrogatives formulate a just-observed conduct as problematic, and attribute responsibility for it. Since they call for either a remedy of the (embodied) conduct or a contesting of the blame as the next action, noticing breaches marginally qualify as directive actions. At the same time, they do not explicitly provide any guidelines for the future. The study argues that in order to determine function in language it is necessary to study grammatical structures in their temporally emerging and embodied activity contexts. The data are from Estonian instructional and everyday interaction, with English translation.
\end{abstract}




\section{Noticing breaches with non-polar interrogatives: Estonian kes 'who' ascribing responsibility for problematic conduct}

Action formation and ascription is a key field in current interaction research. It necessitates a careful study of both the format of the action as well as its receipt by others (Levinson, 2013). In this paper we target a tight group of linguistic formats, non-polar interrogatives (often called wh-interrogatives in English), which constitute something of a challenge for conversation analysis because they relate to what Levinson (2013, pp. 124-128) calls “nonverbal action streams”.

Questions ${ }^{1}$ have been a central topic in mainstream pragmatics for several decades (e.g. De Ruiter, 2012). Recently, particular attention has been focused on their functions in conversational sequences in institutional settings (Freed \& Ehrlich, 2010) as well as everyday interaction across different languages (Enfield et al., 2010). It has been firmly established that not all interrogatives function as questions, while all questions do not have to be formatted as interrogatives (Bolinger, 1957; Koshik, 2005; Schegloff, 1984; Stivers et al., 2010). It has furthermore been argued that the central task of questions, that of mobilizing a response, is actually a combined achievement of grammatical, prosodic, and embodied features, such as gaze (Stivers \& Rossano, 2010a,b). The current research frontline is thus in the explorations of the real-life embodied usage of interrogatives and their practical achievements as evidenced in recipient behavior.

This paper looks at non-polar interrogatives, scrutinizing conversational turns such as when a mother says to her son: "Dear child, who said earlier today that he would do all his

\footnotetext{
${ }^{1}$ In this paper we use the term 'interrogative' for the syntactic category, and the term 'question' for the functional category. However, terms such as ‘rhetorical question’ are used in accordance with the established tradition.
} 
homework nicely before coming home?”. In its literal, i.e. most frequent usage, a kes $^{2}$ 'who'interrogative asks for information about the actor in the clause, but the interrogatives in our collection do not call for an informative answer. Interrogatives that do not call for an answer are often generally categorized as "rhetorical questions”. Earlier studies on rhetorical questions, most notably Koshik (2005), have already shown the broad variety of actions that they accomplish in real life English interaction, thus problematizing the unified category of “rhetorical questions”. Koshik (2005) demonstrated that questions such as when have I (p. 39) could function as challenges. She also showed that in pedagogical settings, rhetorical questions can be employed in error correction sequences and indirectly convey criticism. The current study will focus on yet another pattern of conveying criticism with a distinct group of interrogatives, but demonstrates that the action is qualitatively different from what has been argued for other kinds of interrogatives in interactional linguistic literature so far, such as why-questions eliciting accounts (Bolden \& Robinson, 2011; Sterponi, 2003). Similar to some interrogative formats, as shown for at least German (Günthner, 2000, pp. 111-113, warum 'why' in Egbert \& Vöge, 2008) and English (the adversarial 'how could/can you' in presidential press conferences, Clayman \& Heritage, 2002, pp. 222-226), Estonian non-polar interrogatives, in particular kes-interrogatives, feature a reproaching flavor. However, the primary purpose of these non-polar interrogatives is to formulate a just-observed conduct as problematic. This type of non-polar interrogative belongs functionally to the cross-section of two broad action categories, noticings and directives.

Noticing is a formulation of some matter in the environment (Keisanen, 2012; Schegloff, 1988). Among other things, Schegloff pointed out that noticings may draw attention to "something which the recipient has failed to do" (Schegloff, 1988, p. 121). Similarly, our non-polar interrogatives formulate something that did not occur, and even

\footnotetext{
2 The word kes can in principle be declined in all 14 cases of Estonian. In the corpora, however, the interrogative formulation of a breach was only found with the nominative.
} 
when they formulate something that did occur, it is something that should not have happened. As we will demonstrate, especially kes-interrogatives regularly formulate a negatively valued past or ongoing event, constituting a clear parallel to Schegloff's famously analyzed turn “You didn’t get en icecream sanwich” (1988, p. 119). He argues that this noticing “remarks not only on the absence of the ice-cream, but also on the relevance, and hence the observability of this absence” (Schegloff, 1988, p. 120). Likewise, our noticings centrally establish the relevance and observability of an absence or a problem, such as when a son has not fulfilled his promise to his mother. Crucially, a noticing is temporally tied to local perceptual context, thus being different from corrections delivered in the aftermath of a performance. The latter have been described by Weeks (1996) at an orchestra rehearsal, e.g. when a conductor utters upon the completion of a piece: "You move too soon after the B-flat careful” (p. 265-266). In contrast, our noticings are produced immediately after, or even during the breach.

Insofar as there is still an option to remedy the conduct formulated in Estonian nonpolar interrogatives, they may belong to the group of directive actions, as understood in the broadest sense: directives are verbal actions used for exerting social control over another (Ervin-Tripp, 1981). However, when it comes to the central aim of directives to get the "hearer to do something” and thus "the world to match the words” (Searle, 1976, p. 11), our non-polar interrogatives do not qualify in a straightforward manner. Prototypically, directives formulate some desirable outcome for the future, while our cases basically formulate the breach. Among Searle’s examples of directives we can find actions such as requests, commands, vows, promises (Searle, 1979, p. 4), askings, orders, commands, prayers, pleadings, beggings, entreaties, advice, invitations, etc. (Searle, 1979, p. 14). All of these contain future-oriented formulations, even when it comes to what Searle calls "conventional forms of indirect directives” (Searle, 1979, p. 37-38), such as "Will you quit making that 
awful racket?”, “Won’t you stop making that noise soon?”, and “Must you continue hammering that way?”, where, indeed, problematic conduct is formulated, but where futureoriented guidelines occur as well (“quit”, “stop”, “(don’t) continue”). Likewise, the linguistic formats of directives classified by Ervin-Tripp (1976) all involve explicit elements that formulate what will have to happen, or conditions and needs for such an event. They include imperatives, need-statements, permission and question directives. The propositional content of a directive is always that the hearer does some future action (Searle, 1976, p. 11). Likewise, a more recent study on directives states that through them "speakers promote the performance of a putatively desirable or necessary action, in the immediate or remote future” (Couper-Kuhlen \& Etelämäki, 2015). Corrections, even those produced during a performance, are typically delivered as directives, such as “Don’t rush” at an orchestra rehearsal (Weeks, 1994, p. 259-260). In short, directive actions are all oriented to the future, while a noticing is essentially backward-looking. It targets something that has already happened (or not), or is currently happening (or not), thus contrasting with most directive actions. In contrast to correctives (Macbeth, 2004), it does not provide the correct alternative. However, in the introduction to his book, Searle (1979, p. viii) also discusses an "indirect directive" that is similar to our non-polar interrogatives in that it only formulates the problem: “Sir, you're standing on my foot”, and only indirectly directs the person to move away. We would like to argue that even this case essentially constitutes a noticing. Likewise, Ervin-Tripp (1976, p. 29) includes a category of hints, such as “The matches are all gone”, which is clearly a negative noticing in Schegloff's (1988) terms, although differently from our cases there is no obvious breach involved. With the current paper we are thus carving out a specific type of action at the crossing point of noticings and directives, which we call a noticing of a breach. 
A noticing of a breach basically expresses that the recipient has acted poorly and should have known better. It can be accomplished as an assertion or an interrogative (see a similar argument in a footnote by Schegloff (2007, p. 87)) and we will focus on the latter. For example, a mis/mida 'what'-interrogative generally formulates a problematic conduct by other, and a kus 'where (to)'-interrogative a problematic direction of movement. A kes 'who'interrogative likewise formulates problematic conduct but simultaneously targets the grammatical actor, ascribing responsibility to the addressed co-present participant. Similar to some questions characterized as “challenging” in English (Keisanen, 2007; Koshik, 2005), all these interrogatives may function as vehicles of exerting influence on the course of the unfolding action. Alternatively, they formulate norms of conduct for a next opportunity, e.g. next time making a promise to the mother, or next time performing the same choreography in a dance class. Without residing to intuitive claims on what is "direct” and "indirect” language use, we will focus on what these formats actually accomplish: a noticing of a behavior as problematic.

We will start by outlining the use of different non-polar-interrogatives in noticings, exploring functional systematicity within this coherent grammatical paradigm and showing that they all constitute different actions and action sequences. We will then focus on kesinterrogatives as a central format of noticing breaches that furthermore stands out due to its capacity to expose and ascribe responsibility for the problematic conduct.

\section{Data and method}

Our data come from video- and audio-recorded interaction in Estonian. They include everyday conversations in families and instructional interaction in dance classes. The materials have been obtained while following guidelines for ethical research and consent procedures. Permission to use the data for research, including the presentation of anonymized 
extracts in research articles, was obtained from all participants. The names have been changed in the excerpts. 23 hours of video and 40 hours of audio-recorded interaction have been searched, mostly from the Corpus of Spoken Estonian at the University of Tartu (Tartu corpus). 9 hours of video data come from dance classes. In these sources we found 24 cases of mis 'what'-interrogatives and 15 cases of mida 'what:PRT'-interrogatives, 12 miks 'why'interrogatives, 6 kus/kuhu 'where'-interrogatives, 4 kuidas 'how'-interrogatives, and single instances of mitu 'how many' and mitmes 'which'-interrogatives used as noticings. The latter four formats are only used for noticing breaches in the institutional setting of dance classes. As to our target format, all-in-all 9 cases of kes-interrogatives were used for noticing a breach, as compared to 179 instances of kes-interrogatives treated as literally asking to identify the actor. This is thus not a frequent practice, possibly reflecting the relatively high face-threat that the format conveys.

Importantly, we only found the breach-noticing usage of kes-interrogatives in asymmetric settings, such as between teachers and students or parents and children. They were always uttered by a person who is prototypically expected to exert control over the local social order. Below we will discuss how these very interrogatives claim authority.

Furthermore, we did not find a single instance of kes-interrogative formulating a breach in telephone calls, even though we went through a substantial amount of data. They occurred exclusively in face-to-face interaction. This finding fits with our analysis below: these kes-interrogatives are addressed to the actor of an ongoing or just completed action that takes place outside conversation and can only be discovered visually. This regularity was less clear for other non-polar interrogatives.

In order to scrutinize the function of interrogatives as well as the interactional consequences of their deployment, we used multimodal conversation analytic and interactional linguistic methods (e.g. Couper-Kuhlen \& Selting, 2001; Schegloff 2007; 
Sidnell, 2010). The analysis embraces contextual factors, such as the activity, participants, local sequential contingencies, and crucially the timing of the interrogatives. It targets the function of the interrogatives as revealed in recipients' subsequent actions, taking into account grammatical, lexical and embodied aspects. We argue that an appropriate functional analysis of language structures has to work at this level of minute lexical-interactional detail, as this is where the regularities that are relevant for the participants can be revealed. From a more theoretical linguistic perspective, grammatical constructions can be seen to set up conditions on prior and subsequent actions, which can be characterized as the "external syntax" that complements the "internal syntax" of a construction (Linell, 2009, pp. 310-314). Structures such as kes-interrogatives are here accordingly conceptualized as dynamic methods of accomplishing actions in specific activity contexts. As we will show, in the case of kes-interrogatives the relevant matters that participants orient to involve primarily embodied behavior.

\section{Noticing breaches with non-polar interrogatives}

A couple of previous studies of Estonian interaction have argued that mis/mida 'what'-, kus/kuhu 'where’- and miks 'why’-interrogatives can function as indirect directives (Metslang, 1980; Laanesoo, 2014, 2017). We therefore started out by a systematic search for potentially non-interrogative uses of non-polar interrogatives in our corpora, and found numerous interactional functions accomplished by different formats (Laanesoo, 2012). A distinct pattern of noticings emerged in the collection, i.e. cases where the non-polar interrogatives formulate some unwanted or missing conduct, and thus target a breach. As a rule, these interrogatives remain unanswered. The relevant response instead tends to be embodied and entail a remedy of some earlier behavior. In the current section we will discuss 
the functioning of five different interrogative formats and then compare them to the accomplishments of the focus pattern, the kes-interrogative.

To start with, mida 'what:PRT' - interrogatives are used to notice and convey a negative stance towards an ongoing embodied action. In Extract 1 a family is playing cards. The daughter (A, Annika) is eating and drops something on the table, after which the son (S) utters a 'what'-interrogative mida sa lödistad 'what are you splattering' (line 3). The interrogative does not receive any response and is instead treated as a prohibition to stop splattering.

Extract 1 Family card game

01 A: \$[ei õnne]stu teil käkki keerata.\$ you don't manage to trick [others].

$02(13.3)$

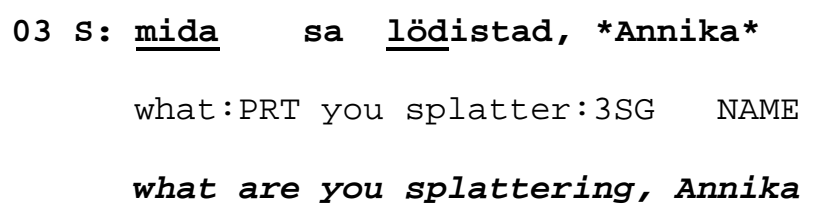

The interrogative in line 3 is not an information-seeking question, as all the participant have visual access to what is being spilled. Similarly, Monzoni accounts for why her challenging questions in Italian are not recognized as information-seeking questions (2008, p. 83): “...speakers have direct access to and have been closely monitoring the very concurrent nonverbal activities the questions address, thus they do not seek information.” With the interrogative in line 3 the son is pointing out his sister's misconduct that should be stopped. Noticing mida-interrogatives are used in this way to indicate that the addressee's behavior is 
unreasonable or inappropriate. The interrogatives characteristically include negatively loaded verbs, such as the derogatory lödistad 'splatter'. The negative stance is further supported by distinct strong stress and pitch accents, which set it apart from mida-interrogatives looking for informative answers. (Laanesoo, 2014) The spill has already happened, so the above mida-interrogative just emerges as a judgement on Annika's current behavior, which by implication prohibits its continuation as well as formulates the norms of composure. The format thus peripherally belongs to the category of directive actions. Crucially, our target turn stands entirely separate from the rest of the conversation around the card-table, orienting to Annika’s embodied conduct.

A closely related format of noticing breaches is illustrated in Extract 2, where a misinterrogative ('what' in nominative) is addressed to a baby. The fact that the formats of our interest are regularly addressed to non-speaking participants underlines our argument that they do not call for a verbal response.

Extract 2 Dinner (Tartu corpus)

$01 \mathrm{M}$ :

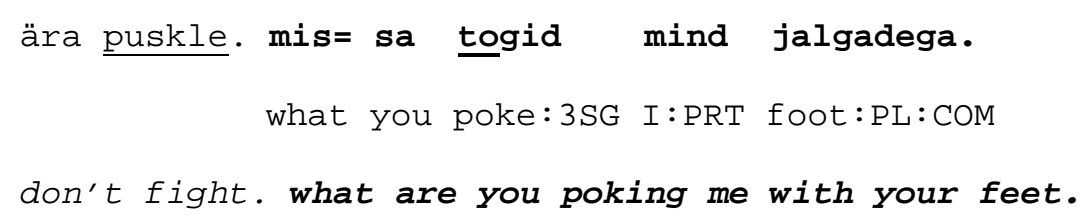

Similar to the previous example, the mis-interrogative in this excerpt is not placed in a sequential slot within a conversation. Only the mother and the baby are present and there are long silences before and after the target turn. The interrogative formulates an embodied action that is socially unacceptable (kicking the mother), and implicitly prohibits its continuation. It is furthermore preceded by an overt directive to stop fighting. Similar to the 
above mida-example, it includes a derogatory verb togid 'poke'. The interchangeable misand mida-interrogatives are thus essentially prohibitions of the noticed conduct, which may in this case also include verbal conduct (e.g. mis sa seletad. 'What are you blabbing'). They are unanswerable as questions and may be paraphrased as “Don’t splatter!”, “Don’t poke me!” and “Don’t blab!”.

Quite differently, miks 'why'-interrogatives can be used to notice a breach but besides prohibiting the conduct, they may also formulate a lacking one. Excerpt 3 displays a case in our collection where a dance teacher uses a miks-interrogative to target problematic conduct during the performance of a choreography.

Extract 3 Swing dance class

((dance ongoing, just before the turn in line 1 Eveli is supposed to look at Vaigo))

01 Teacher: Eveli. +miks sa üldse ei vaata Vaigo suunas. NAME why you at.all NEG look NAME:GEN towards Eveli. why are you not at all looking at vaigo. student +stops dancing, turns to look at the teacher

This interrogative calls for a remedied performance of the choreography at a next opportunity, thus implicitly amounting to a guideline for Eveli to look at Vaigo, i.e. as a paraphrase “(Next time) look at Vaigo!”. Alternatively, it can be treated as asking for an account for a norm-breaching conduct, which is very different from the above mis/midainterrogatives. Similar problem-implicative and account-eliciting use has been described for the German warum 'why' (Egbert \& Vöge, 2008) and the English why (Bolden \& Robinson, 2011).

In yet another pattern, kus/kuhu 'where (to)'-interrogatives effectively stop the recipient from moving (in the wrong direction). Based on intuitive and literary sources, it has 
for long been established that an utterance such as Kus sa lähed? 'Where are you going?' may convey “Don’t go!” in Estonian (Metslang, 1980, p. 109). On the basis of videorecorded interactional data we were able to document the exact timing of these interrogatives and analyze their treatment by the recipients. A kus-interrogative in a dance class literally stops the student(s) from moving. In one case a lady who does not have a partner starts moving away from the dance floor. The teacher utters Kus sa kaod Anneli. 'Where are you disappearing Anneli.', upon which the addressed student immediately stops walking. The teacher then (re-)states the rule that the student should be following instead Palun siia tuleb see: üksik: neiu. 'Please the single lady comes here.', and the student follows the teacher's guidelines. Similar to the above cases of mis/mida and miks, kus-interrogatives of this type formulate a noticed conduct in negative terms (“disappearing”). The student’s silent response, the stopping, reveals her understanding that her current movement is problematic. As a critique of the current movement, a kus-interrogative is typically uttered in an abrupt manner, with the prosody reinforcing the urgency of stopping.

Somewhat differently still, a kuidas 'how'-interrogative can be used to formulate a problematic bodily conduct and invoke a remedy. In Extract 4 the dance teacher notices a wrongly held hand with this format. A student has placed herself in the position to begin an exercise and the teacher targets her posture before she can start in line 1.

Extract 4 Ballet class

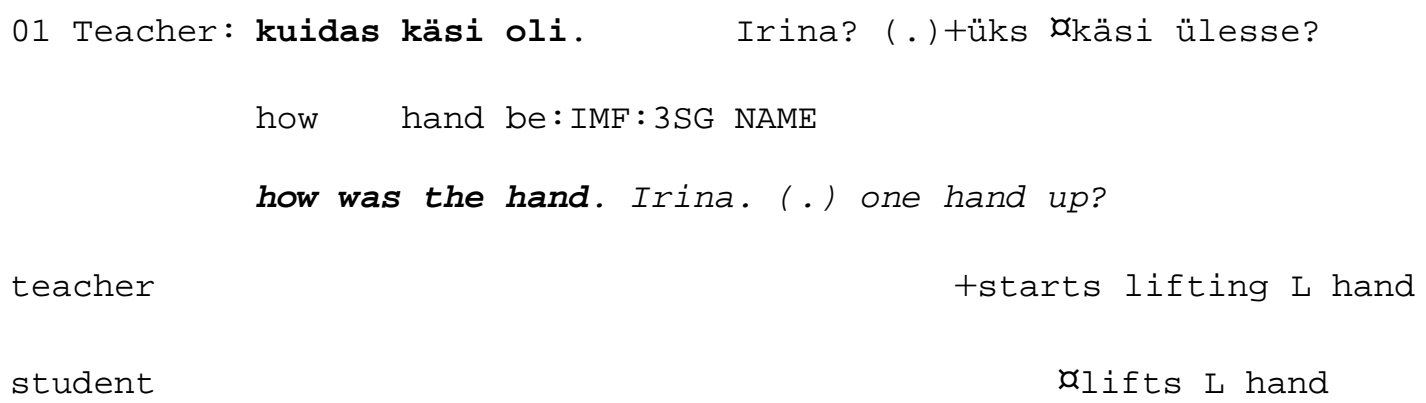


the other hand?

○4 Teacher: ( $(\mathrm{L}$ hand down, $\mathrm{R}$ up $)$ )

05

o6 Student: ( $(\mathrm{L}$ hand down, $\mathrm{R}$ up $)$ )

07 Teacher: $\{$ nii $\}$

okay

The kuidas-interrogative implies that the hand is in the wrong position and provides an opportunity for the child to improve the position. Both the interrogative form and the past tense underline the fact that the addressee should have known the hand position, which she does not, so there is no reaction after the name Irina in line 1, and the teacher then prompts the student step-by-step to the correct posture and the choreography of switching hands up and down.

In summary, each of the non-polar interrogatives we have shown so far functions slightly differently in noticings: while mis/mida-interrogatives target the negatively formulated action as problematic and constitute prohibitions, miks-interrogatives may formulate a lacking behavior and offer an opportunity for an account, kus-interrogatives function as stopping devices, and some other interrogatives, such as kuidas, target various visible problems. Accordingly, the different formats enable a partly different range of responsive actions: discontinuing the formulated problematic action ('splattering'), doing the action formulated as a negative noticing and understood as missing ('not looking at Vaigo'), halting the movement ('disappearing'), adjusting a body position ('hand') etc., which demonstrates the speakers' distinctive ascription of action to each of these formats. Their sequence structure, the so-called “external syntax” (Linell, 2009) is different, even though all the formats feature as noticings of a breach by the addressee and thus call for a remedy of the noticed conduct by him/her. 
Our focus format, the noticing kes-interrogative, stands out in this broader picture as having a distinct capacity to ascribe responsibility and blame. While other interrogatives target problems with actions, moves, reasons, and directions (what?, how?, why?, where?), a kes-interrogative targets the actor. The information focus is not on the problematic conduct itself but on those producing it. And since kes literally asks for the identity of the actor, the use of address forms in the same turn becomes considerably more puzzling than in the above cases, where they were used to single out the addressee. Furthermore, a kes-interrogative is more complex in its ability to implicitly convey either a prohibitive or ordering action (cf. mis/mida, kus used for prohibitions, miks for orders), thus necessitating a more granular analysis. Finally, there is to our best knowledge no analysis available on the non-literal use of 'who' or 'who'-interrogatives in any language. In the following section we will revisit the central features of noticing breaches in a detailed analysis of a sample kes-interrogative, after which we will discuss its features in everyday vs. institutional interaction.

\section{Target practice}

Extract 5 provides a sample case of a kes-interrogative from our dance class data. The teacher is counting beat numbers one, three, five, and seven to accompany the students' dance. On the word viis 'five' in line 2 there is a lift by one couple, as shown in Figure 1. After counting to the end of the musical phrase (seven) the teacher utters a kes-interrogative that formulates the 'lifting' as problematic, followed by the addressee’s name Ergo, which is prosodically latched to the interrogative (line 3).

Extract 5 Dance class (Lindy Hop corpus)

01 Teacher: üks (.) kolm (.) viis (.) seitse

one (.) three (.) five (.) seven 


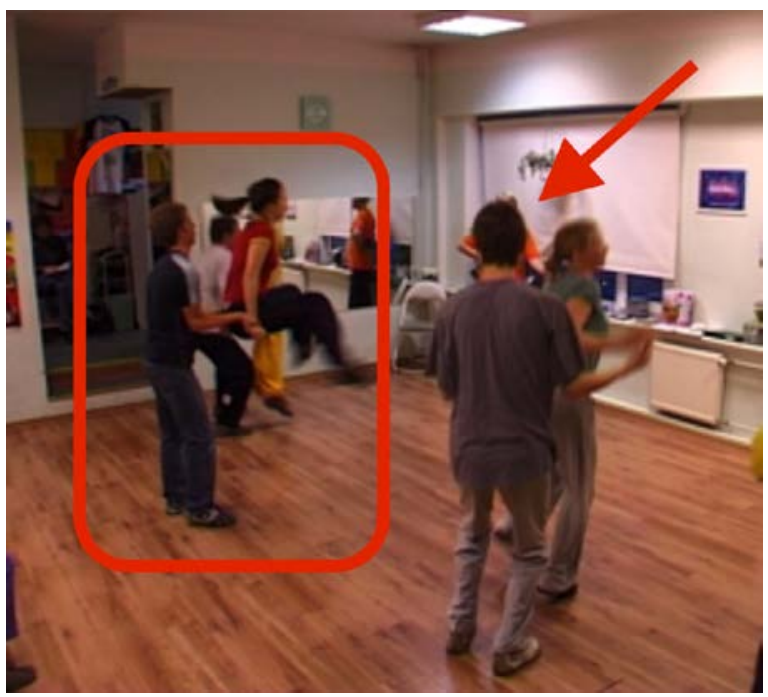

Figure 1. Lifting the partner too low: the teacher stands behind the students and is pointed out with an arrow; the target couple is surrounded with a rectangle

The teacher then goes on to produce what Sacks has called the correction-invitation device (Sacks, 1992, pp. 21-22), namely an incorrect account 'A crane?', which is designed to solicit a substitution with a valid one. This ironic proposal continues to pursue the issue of lifting, after which the teacher stops talking and the students continue to dance.

Several important aspects of the kes-interrogative can be pointed out here. It is not placed in a sequential slot within a conversation but occasioned by something outside the talk, which it brings to common attention. It thus qualifies as a "noticing” (Schegloff, 1988; Keisanen, 2012). The noticing is temporally fitted to the dance time, which is something the teachers always have to negotiate during a class (Keevallik, 2015). Importantly, the kes- 
interrogative points out a breach - someone is not properly performing the lift that is normatively expected at this point. In normatively oriented activities, such as when learning a skill, the central task of a teacher is to correct the students. However, differently from the corrections discussed in classroom setting (Macbeth, 2004) and orchestra rehearsals (Weeks, 1996), kes-interrogatives merely formulate the problem and do not provide information on the correct alternative (here: how to improve the lift).

Crucially, the kes-interrogative ascribes the responsibility for the mistaken move to the lifter (and not the liftee, who has to jump). It literally asks for an actor for the action of 'lifting', but in effect singles out an addressee and ascribes the blame to him. Already the verb choice tõstab 'lifts' target a distinct group of participants in the class, the three lifters. Even though the teacher's gaze seems to be on the addressee, this can be difficult to perceive while in the middle of a dance. A specific person is then explicitly addressed by his first name, Ergo. Names are regularly used to accomplish a change in the participation framework, seeking the attention of another present party (Lerner, 2003). Here, too, Ergo works to definitively single out one recipient among many, for the benefit of all participants in the class. This combination of components results in the fact that the kes-interrogative does not elicit an informative answer, and could very broadly be classified as a rhetorical question. As is typical of rhetorical wh-questions at least in English, it is "uttered in a context which cancels certain otherwise possible answers” (Bolinger, 1957, p. 157). Theoretically, anyone present in the class in Extract 5 could provide a correct answer to the kes-interrogative, perhaps by themselves being aware of a fellow student's less-than-perfect performance, but definitely after the name has been uttered. As the choreography proceeds beyond the noticing of the breach, the only immediate reaction to the teacher’s turn is Ergo's slightly disappointed head tilt, a possible acknowledgement of the teacher’s remark. 
The appropriate next action to the noticing of a breach in this context is an improved performance of the lift at the next opportunity to perform the same choreography. In that sense, kes-interrogatives peripherally qualify as directives, acts which amount to "an attempt to get H[earer] to do something” (Searle, 1969, p. 69). A paraphrase of “Who’s lifting, Ergo?” could be something like "You need to lift properly, Ergo!”, which urges for a remedied performance from Ergo. Crucially, kes-interrogatives only point out the problem that has just occurred, as in the current excerpt, or is currently happening, thus being dissimilar from prototypical directive actions, such as orders, commands and requests. Accordingly, while some polar question formats, such as "would you X" and "will you X" have been acknowledged as conventionalized forms of requests in different languages (e.g. Heinemann, 2006; Curl \& Drew, 2008), 'who'-interrogatives have not been characterized as such. As a special kind of noticing, kes-interrogatives regularly bring a problem to public attention, which among other things implies a claim to authority by the speaker. It happens though, that the students in a dance class object to the ascription of blame. It is thus also possible to contest the noticing. This sequence of actions can be schematically presented as follows:

\section{A BREACH-NOTICING SEQUENCE WITH KES-INTERROGATIVE} ((ongoing activity))
A: $\quad$ kes-interrogative formulating B's conduct as noticed (+ address term referring to B)
B: remedying the conduct or contesting the blame

\section{Kes-interrogatives as noticings in an everyday setting}

Moving to everyday interaction, we will now show how kes-interrogatives are used to address a recipient's breach in mundane settings. A case in point (Extract 6, continued in Extract 7) 
takes place between a mother and her 11-year-old son. The kes-interrogative formulates an action, an earlier promise, as unfulfilled. There are five people present - mother (M), stepfather (F), son (S), daughter (D) and a friend who is visiting the family (G). The extract starts when the son takes out his textbooks and starts to do homework. So far, the adults have been having a conversation among themselves and the son has been minding his own business. While the guest is finishing her story about a radio, the mother turns her gaze towards the son (line 2) and utters the following: 'Dear child who said today that he would do all his homework nicely before coming home’ (lines 6-7).

Extract 6 Family evening (Tartu corpus)

$01 \mathrm{G}$ : no (.) midagi sellist aga veel prostam mingi=üts well (.) something like that but more simple

$\odot 2$ kuuekümne krooniga sai. (0.5) aga +levi:=ei she said that she got it for about 60 crowns. (0.5) but it

m +looks at $S^{\prime} \mathrm{S}$ exercise book/ leans towards $S$-->

03 G: noh ei=saand kä[tte. ] didn't get the channels.

04 F: [nojah] right

$05 \quad(1.5)((M$ swallows $))$

$06 \mathrm{M}$ : +akallis laps kes=se rääkis täna et ta õpib dear child who this tell:IMF:3SG today that he study:3SG dear child who said today that he would do all his homework

07 \$küla pääl ära ilusti.\$ \#2 away.from.home ASP nicely

nicely before coming home.

m $\quad$ tgazing at S/grinning -->

s agazing at exercise book --> 
$\odot 9$ S: ma=i [ütelnud, ]

I NEG say:PPC

I didn't say,

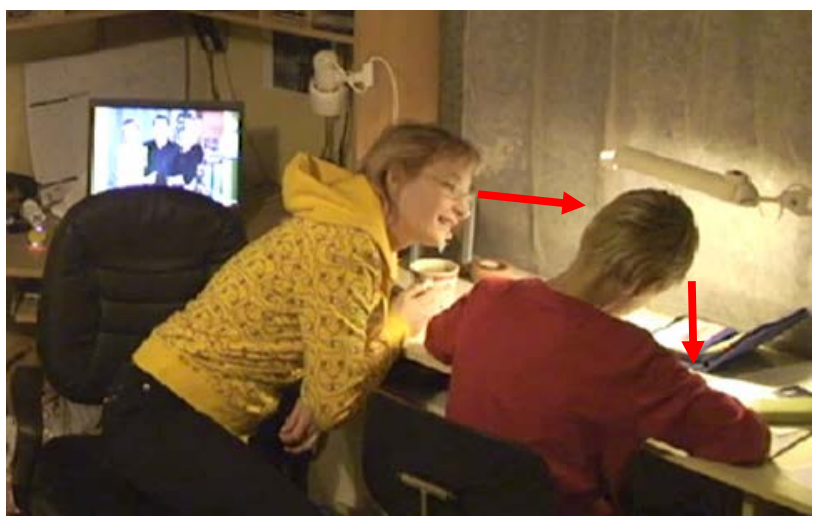

Figure 2. Mother leaning in at son's homework desk; arrows show the direction of gaze

In line 2 the mother leans towards her son, invading his personal space (as shown in Figure 2). She holds this posture as well as a grin throughout the target utterance in lines 6-7, intensely looking at the son who keeps his gaze on the textbook.

The kes-interrogative here first of all reflects the mother's understanding of the son's current actions as representing homework yet to be done. This is basically a noticing, but the format it takes is more complex than in Extract 5. Nevertheless, the interrogative is triggered by an ongoing action and it formulates an event from the recent past. It is therefore constructed in the past tense ('who said') and continues with an indirect quote ascribed to the son. Similarly to Extract 5 the interrogative is uttered from a knowing position, and thus does not seek the identity of the actor of the action depicted in it. Furthermore, the interrogative pronoun kes 'who' is followed by a prosodically latched demonstrative pronoun se(e) 'this' (in line 6), which in its particle-like use is regularly used to index referents identifiable both by the speaker and the hearer (Pajusalu, 1997, pers. comm.). This is yet another feature that indicates that the actor is known to the speaker. Paraphrased, the mother's turn conveys the 
past-oriented message "You should have done your homework before coming home as promised”.

The kes-interrogative is prefaced by the address form kallis laps 'dear child' that together with the leaning, the gaze and the lower voice singles out the son, even though there is another child present in the room. Although address terms in multi-party conversation, as this one, are regularly used to select the next speaker (Lerner, 2003), they may also indicate an interactional problem and establish authority (Butler, Danby \& Emmisson, 2011; Clayman, 2013). Indeed, the endearment kallis ‘dear' here sounds ironic and ominous, conveying authority, especially in combination with the upcoming noticing of a breach. One could also argue that it aggravates the reproaching flavor of the utterance.

The kes-interrogative formulates a promise made previously to the current speaker, the mother, and implies that the son has breached a social contract between them. The noticing points at two problems: (1) the son has made a promise, which he did not fulfill, (2) the homework is not done, which stands as evidence for the existence of the first problem. By insinuating a breach that has evidently already taken place, the turn calls for remorse, apology, or an account of disability. The son, however, chooses to challenge the mother's claim by ma=i ütelnud 'I didn’t say' (in line 9). He contests the ascription of the quote and thereby implicitly also the responsibility, orienting to his mother's turn as a noticing of a breach.

The son cannot finish his turn before the guest formulates the gist of the noticing, 'now everything is still to be done' (Extract 7, line 10), and the son's next defensive turn (line 12) addresses the concept 'everything': ei ma=i=öelnud et ma kõik 'No, I didn’t say that I would (do) everything'. This utterance is prefaced by the correction device ei 'no' (Keevallik, 2012, pp. 128-129). The son continues to fight back against the insinuation of a broken promise in lines $(9,12,15)$. If he had promised to just do part of the homework, his current 
activities at the desk would be justified. All his defensive responses come in overlap with others, as he tries but fails to get the floor. His tone of voice is aggravated and serious, while the grown-ups playfully tease him for not having done the homework. Additionally, the mother states that he had logged in to MSN (online instant messenger) during the afternoon (line 16-17), which is a matter that may have affected his ability to do the homework. Similarly to the kes-interrogative turn, the son treats this turn also as a formulation of a breach - by uttering definite ei 'no' (line 18) in response, he does not accept the responsibility for this alleged misconduct either. At the beginning of the turn, he also lifts his gaze towards mother (Figure 3). This is different from his reaction to the first noticing of a breach, where he did not lift his gaze from the exercise book. By that he is possibly upgrading the contesting of the blame.

Extract 7 Family evening, continued (Tartu corpus)

10 G: [ja nüüd on] [kõik õppimata. ] and now everything is still to be done.

$11 \mathrm{~F}$ : [oijaa [oligi $\{-\}$ ]] that's true, it was

$12 \mathrm{~S}:$ [ei ma=i=öelnud] [et ma kõik ] no I didn't say that I'd everything

$13 \mathrm{M}$ : [@ai @ sa=i=öelnud] aargh you didn't say

14 F: [sõbra? ]

friend?

15 S: [ma ütlesin] [alguses et ma õpin. mh] at first I said that I was going to study. mh

$16 \mathrm{M}$ : [.hhhh aga arvu-.hh ] aga arvuti .h but the comput-. hh but the computer 17 näitas=et sa=lä- ä logisid sisse emmessenni ennast. 
showed that you logged in to MSN.

18 S: a\#3 ei?

no?

s alooks at $M$

19 G: .haa \$ e:::i noh heh .hh [räägi ära?]

.haa no:: come on confess?

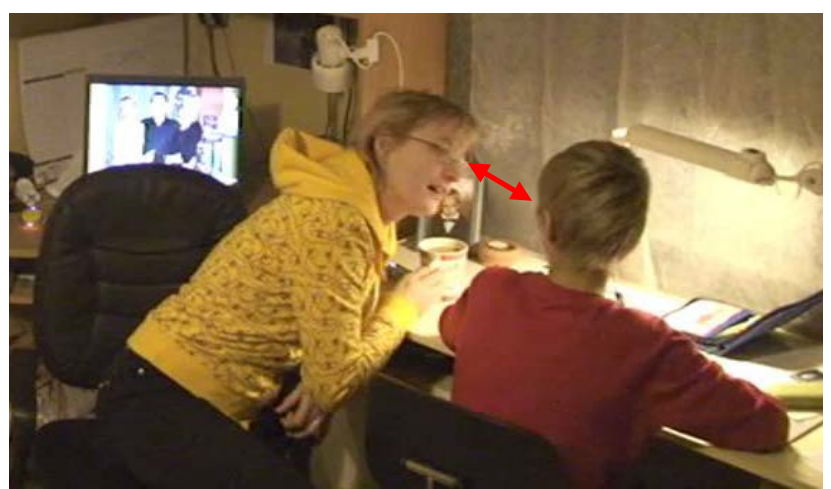

Figure 3. Son returning mother's gaze

In short, the kes-interrogative in Extract 6 reveals similar features to the one in Extract 5 . The noticing is occasioned by something outside the ongoing talk, the son starting to do his homework, which signals problems to the mother. The kes-interrogative formulates a conduct which evidently amounts to a breach. It is simultaneously a claim to authority, in this case enhanced by the mother's physical invasion of the recipient's personal space. The interrogative is not treated as a question calling for an informative answer, but a noticing of a breach to be contested. By implication, the interrogative conveys the social norm that promises should be kept and thereby functions as a moral guidance for future occasions. The kes-interrogative thus works to exert social influence (Hepburn \& Potter, 2011), as a peripheral instance of a directive. 
This function of noticing a breach is further illustrated in Extract 8, which displays a kes-interrogative addressed to a $\operatorname{dog}^{3}$, who of course cannot talk in response.

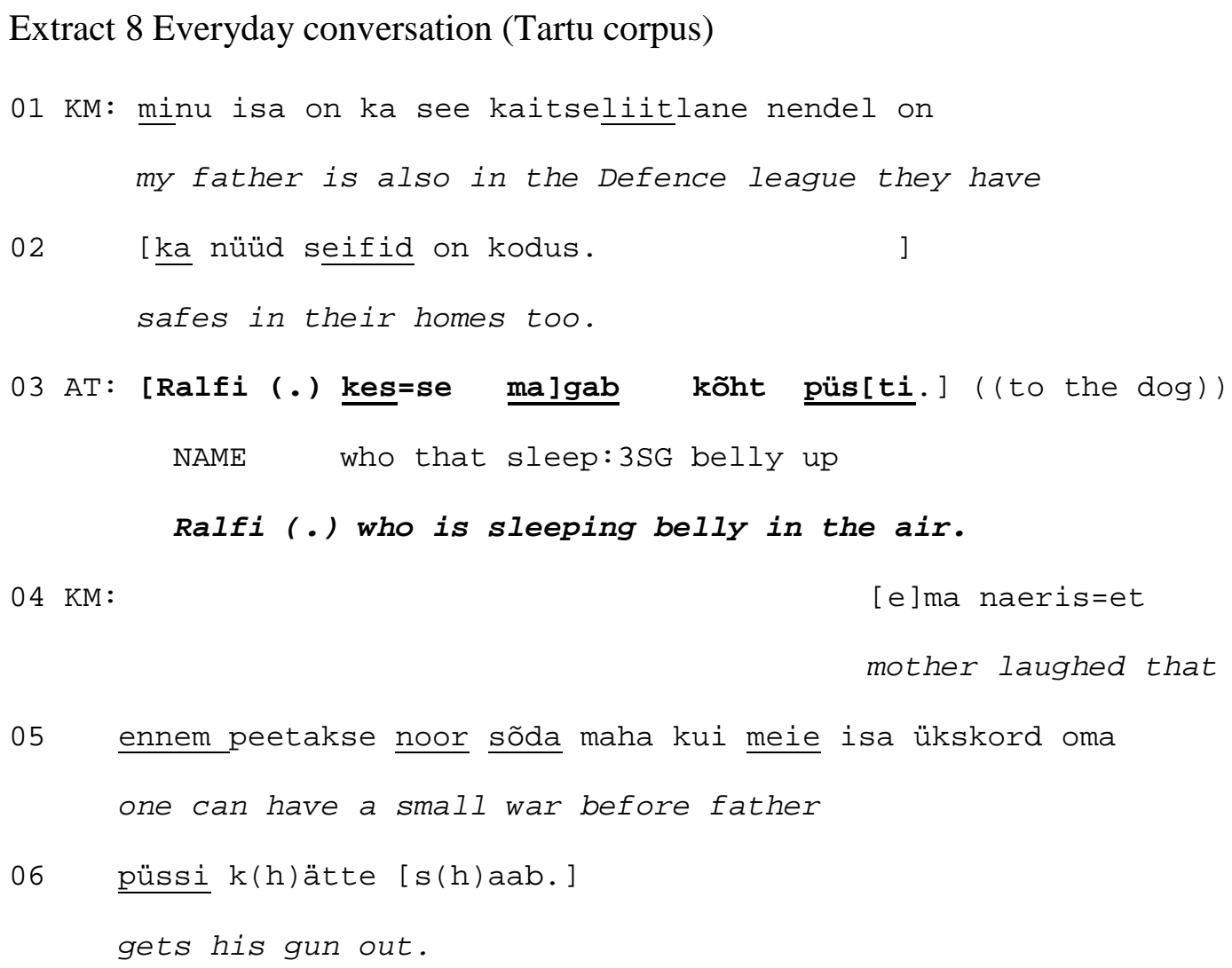

Interrogatives in the above excerpts $(6,8)$ are not placed in a sequential slot within the ongoing conversation and do not at all orient to what was just said. In Extract 8, the interrogative is furthermore produced in overlap. The interrogative formulates embodied action, sleeping in an ungraceful manner, and implicitly functions as a directive to stop doing it, thereby claiming authority. Typically for kes-interrogatives, the name of the addressee, Ralfi, is used, this time before the interrogative. It identifies the targeted actor and treats him as responsible for the formulated action. The kes-interrogative accordingly features a special

\footnotetext{
${ }^{3}$ Human-pet interaction has been studied from different aspects. For example, Tannen (2007) shows among other things how speakers use dogs as resources to praise their interlocutor, to mitigate criticism and to bring humorous tone to an argument. Even in our case, the noticing of a breach may well be done for the benefit of the human audience.
} 
sequence structure, the so-called “external syntax” (Linell, 2009), being timed in relation to the past or ongoing breach, and calling for a remedy or contesting the blame as the appropriate next action.

\section{Kes-interrogatives as noticings in an instructional setting}

One type of setting where noticings of breaches recur is instructional activities that involve an expert and novices. Among other pedagogical devices, the experts observing novices’ practice can format their noticings as kes-interrogatives. A kes-interrogative grammatically focuses on the actor, the one responsible for the conduct, and specifically formulates the problematic action (we have seen formulations such as 'told X', 'lifts', and 'sleeping belly in the air'). This renders it a special reproaching or shaming quality. Even though in most cases the responsible actor is selected with a name, a kes-interrogative can also be used to address several actors, as the pronoun is neutral in number. This is illustrated in Extract 9 from a dance class. The teacher first counts in the students: 'and five six seven' in line 1 . She then continues to accompany their dance with some non-lexical vocalizations, padim padah, as well as precision-timed prompts of the dance moves, such as 'right leg' in line 2. During padim in line 3 the dancers are supposed to shake their shoulders in a position shown in Figure 4. Apparently, the teacher finds the shoulder shake not up to standard, as in her subsequent kes-interrogative, she formulates that as a problem. The English translation of the target line is deliberately non-idiomatic, as none of the idiomatic wordings correspond to this particular format.

Extract 9 Dance class (Lindy Hop corpus)

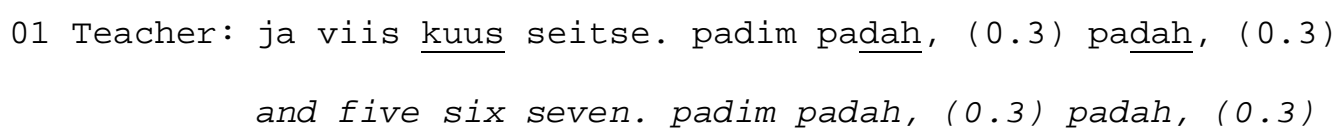


pa:rem jal:g ja va:sak jal:g.

ri:ght le:g and le:ft le:g.

$\odot 3$

padim \#4 padah, (0.3) padah, (0.3)

padim padah, (0.3) padah, (0.3)

$\odot 4$

kes küll õl:gu liigu-tak:s.

who PART shoulder:PRT:PL move:COND

who would shake the shoulders.

05

ja ôlad ja õlad, shimmy on nendega,

and shoulders and shoulders, shimmy involves them,

06

.hh ja pim paa paa jah?

.hh and pim paa paa and?

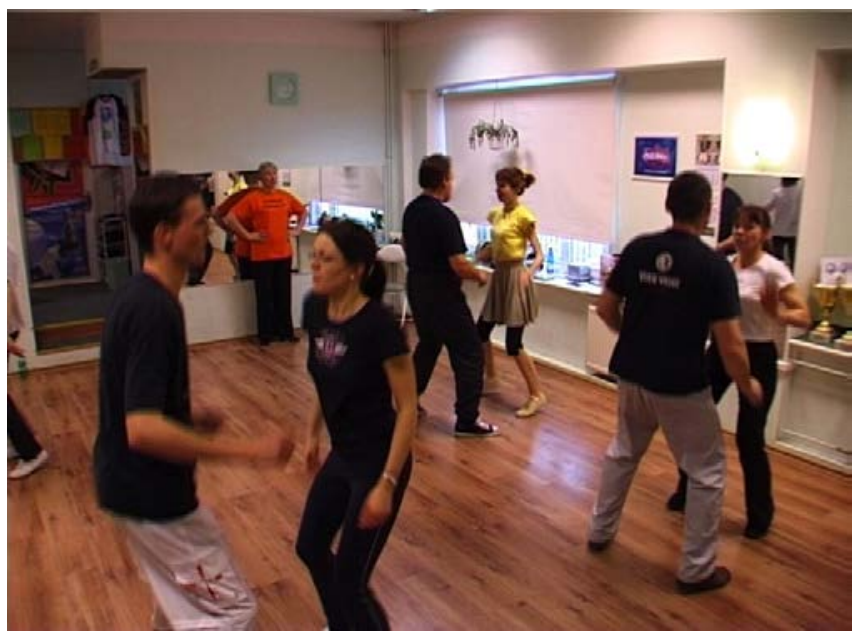

Figure 4. Too little shoulder shake: the teacher is standing in front of the mirror in akimbo position

The teacher's kes-interrogative is interesting in many ways. First of all, it targets everybody, as no particular addressee is pointed out by name or gaze. The teacher is gazing towards the center of the studio. Second, it is grammatically in a conditional form liigutaks 'would move', which in this case functions to construct a wish (Pajusalu \& Pajusalu, 2004, p. 256). Third, the untranslatable particle küll sets a pragmatic focus on the initial element in the 
clause (Hakulinen \& Keevallik, 2016), here on kes, and thereby sets the spotlight on the actors. The interrogative clause could thus be paraphrased as something like "Who would be the one to shake the shoulders?” Throughout the production of the utterance, the teacher continues to talk rhythmically, coordinating the continuation of the dance. There is no music playing here, and in her rhythmic talk, the teacher simultaneously caters for the dance-inprogress as well as the instruction. Finally, the termination of the kes-interrogative is precisely timed with the moment when the shoulder shake called shimmy is to be repeated in the choreography. During the subsequent line 5 when the teacher prompts 'and shoulders and shoulders' the students have to repeat the previously mistaken shoulder shake. Indeed, the shoulder shake looks better this time. A precision-timed noticing that ascribes responsibility to the group of students has thus here also emerged as a directive.

Several noticings of breaches in the dance classes (Extracts 5, 9) are produced during ongoing dance without intervening with it. They emerge as noticings precisely because of their exact timing with the dance performance, and build action sequences that are only partly verbal. They are reactive to embodied conduct and elicit an embodied response, an improved dance move. In this instructional setting various non-polar interrogatives claim authority and superior expertise over the task at hand. While several of them can take a negative stance on what the students are currently doing, or have just done, a kes-interrogative explicitly targets agency and attributes responsibility to the addressee, who may be publicly selected by name, gaze or category label.

\section{Kes-interrogatives ascribe responsibility}

In the above we showed how a range of non-polar interrogatives are used for noticing breaches in everyday and instructional activities, and argued that the kes-interrogative stands 
out for its capacity to ascribe responsibility for the breach. In the last section we will dissect the details of this distinct practice.

Component features: “internal syntax”

A breach-noticing kes-interrogative minimally consists of the initial pronoun kes and a verb in $3^{\text {rd }}$ person indicative or conditional, present or past tense. The verbs refer to conduct that is in some sense problematic in the current setting and for the current addressee (either formulating what has to be done, e.g. 'move (the shoulders)' as in an order, or what should not be done, e.g. 'sleeping belly in the air' as in a prohibition). This illustrates how meanings are always locally negotiated.

The interrogative format enables the speaker to formulate a breach and formally call for an answer, such as 'me', that accepts responsibility. A kes-interrogative formulates a problem and targets the actors, who are known both to the speaker and the recipients. The speaker implies that she knows that the hearers know that the speaker knows the answer to it, which is why an informative answer is not due. However, interrogatives are as a rule addressed to "knowing recipients” (Heritage, 2012), and therefore the kes-interrogatives in our study have the connotation that the recipient should have known better and, accordingly, acted in a different manner. In contexts where the target problem can still be remedied, kesinterrogatives may function as directives that call for an improvement or halting the conduct. Alternatively, they can be resisted and contested.

The addressee of a kes-interrogative may be explicitly mentioned in the proximity of the interrogative, through names or endearment terms, such as 'dear child'. The address forms are regularly prosodically incorporated into intonation units together with the interrogatives. In all the above cases, the addressees were self-evident in the context, either because they are visibly available (pets) or because an activity-specific category of 
participants is defined (e.g. the verb 'lift' implies “lifters” in the dance class setting).

Addressing by name has been argued to be a means of establishing power among speakers of English (Clayman, 2010, 2013). Turn-initial address forms can also be used to reinforce social roles, such as counselor vs. client (Butler, Danby and Emmisson 2011). In our data, address forms indeed achieve reorientation in the participation structure and locate a single addressee among many present people, but they can also reinforce the power and social role of the teacher or a parent.

As yet another formal feature, the demonstrative pronoun see 'this' may be used immediately after the question word. It is regularly prosodically latched to the question word kes in spoken Estonian, forming the compound kesse (Keevallik, 2003, p. 347). The Estonian see has been shown to mark recognizability of the referent for the recipient (Pajusalu, 1997), which is also what we have argued above for the referent of the pronoun kes. The double format kes + see thus seems to convey a stronger sense of the joint knowledge of the referent. Furthermore, demonstrative pronouns, such as see, can be used for distancing purposes (Erelt et al., 1993, p. 209), which also fits the breach-noticing profile of our target structure. The cases involving the compound kesse thus enforce a distance and perhaps also imply more shame than the ones with only kes. In comparison to the disyllabic and stressed kesse, in other non-polar interrogatives the pronoun sa 'you' only appeared in its shortest form and unstressed. Agency was not in focus in these.

In short, the referent of kes is made clear in our pattern. It designates an animate subject, thus referring to the actor of the activity formulated in the predicate, and he/she/it is also the main addressee. Interestingly, kes thus functions as a regular non-interrogative personal pronoun in our pattern, referring to 'you'. This shows how context-free grammatical categories, such as interrogative vs. non-interrogative pronouns, known vs. unknown referents, may be transgressed in real interaction. 
Action sequence: "external syntax"

In the section “Target practice” we sketched the sequential pattern of breach-noticing kesinterrogatives. The prime condition of their use is an ongoing embodied activity, (some aspect of) which they formulate as problematic. They thus constitute noticings, as originally defined by Schegloff (1988) and further described in Keisanen (2012) who looked at noticings of trouble while driving.

The expected response to this type of kes-interrogative is some kind of remedy of the formulated activity. As all questions, kes-interrogatives are addressed to knowing recipients, but in contrast to regular information questions, our kes-interrogatives also involve known information to the speaker, i.e. the asker here already knows the answer. An informationseeking kes-question asks for the actor and in the answer, the recipient is expected to provide a name or a description of the actor, such as in Kes seal on? - Eva. 'Who's there? - Eva.' When used for noticing, the actor is instead made clear by its timing in relation to ongoing or earlier actions, the speaker's embodied behavior (gaze, head turn), or explicit address terms. A noticing kes-interrogative thus hints at equal epistemic access by the participants, and does not call for an identification of the actor.

Nevertheless, occasionally the noticing of a breaching kes-interrogative can be treated at face value as an information question. This is illustrated in Extract 10, also from a dance class. The teacher uses a kes-interrogative to point out a lack of a push: one of the students, Laura, stayed in place instead of being "pushed” to a different position. In her turn, the teacher explicitly targets "Laura’s partner” and turns her head to gaze at him. The addressee chooses to treat it as an information question by answering 'Me'.

Extract 10 Dance class (Lindy Hop corpus) 


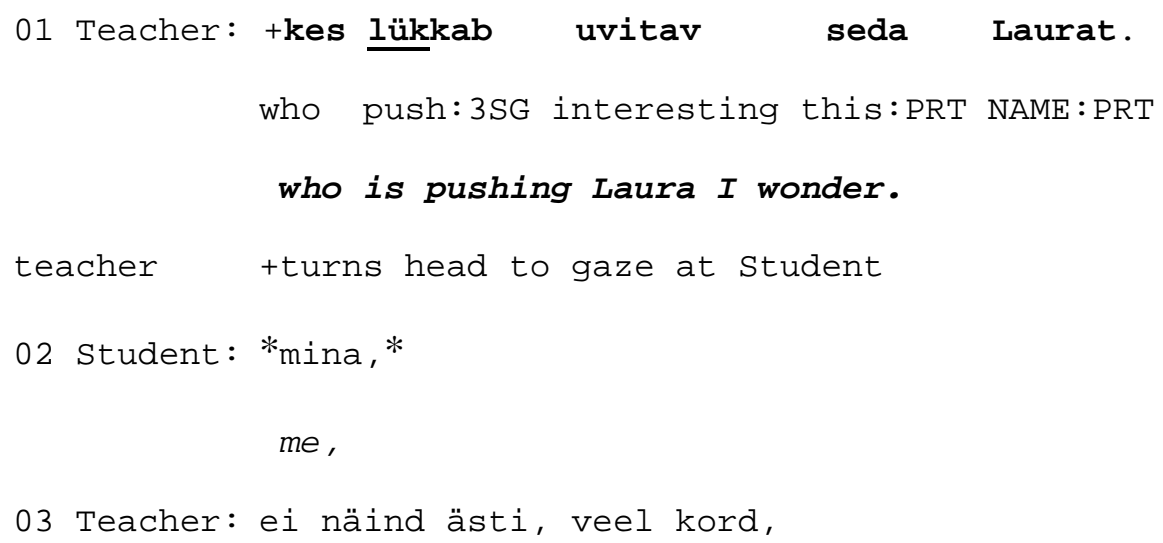

It is possible that the exact wording of this turn occasions the literal answer. By adding uvitav 'interesting/I wonder' the teacher indicates that “the availability of relevant knowledge among the participants is uncertain” (Keevallik, 2011, p. 65), which reduces the clarity of responsibility ascription in this particular case ${ }^{4}$. In any case, the answer accepts the responsibility for having to push Laura. As the student answers very softly with his head hanging and gaze on the floor, the response clearly amounts to accepting the blame. It cannot be heard as a justification for having done the push. The teacher subsequently restates the problem, that the conduct was visibly lacking (in line 3), thereby underscoring her prior action as having been a noticing of a breach. In line with that, she also demands an immediate new performance of the push by uttering veel kord 'once more'.

As a rule, a noticing kes-interrogative does not receive a straightforward 'me' answer, which is nevertheless the projected one, and the reason why the interrogative is a suitable means of ascribing responsibility. This is yet another feature that differentiates the various non-polar interrogatives, as none of the others can be answered with a personal pronoun; none of them focus on the actor. As we showed, the recipients of kes-interrogatives regularly either made attempts to remedy their conduct, or contested the noticing, refusing to take

\footnotetext{
${ }^{4}$ We are grateful to an anonymous reviewer for wondering about this detail.
} 
responsibility for the formulated action. This participant orientation constitutes the ultimate proof of our functional analysis of the kes-interrogative.

In addition, the exact valence of a kes-interrogative is determined by contextual factors: it may function more or less as an information-seeking question, and more or less as a noticing of a breach, depending on the valence of the action described in it. In the current paper we have described one end of the continuum, the non-informative breach-noticing use. Indeed, there may be a different practice of endearing use, where word choice, grammar, prosody and the context co-construct the sense of the kes-interrogative differently, which in particular speakers of English keep reminding us of with their formulaic “Who’s mommy's little X”. However, we only have one possible case of that in our Estonian data, addressed to a cat, and perhaps featuring irony: Kes on nii tubli olnud siin. 'Who has been so brave here'. Similarly to the English phrase, this particular interrogative does not formulate an action (but a category or property: cf. 'mommy’s little X', 'brave'), which is an essential grammatical feature in our breach-noticing pattern. We have not been able to locate even anecdotal evidence of praising use of kes-interrogatives in Estonian. More research in intimate contexts may reveal different patterns, while the data available to us form instructional activities instead enabled us to discover the systematics in a variety of breach-noticing non-polar interrogatives.

\section{Action formation: noticing breaches and social order}

In the above we demonstrated that non-polar interrogatives, in particular kes-interrogatives, are regularly used for noticing breaches, as revealed in participants' responses. We thereby contribute to the increasing body of research on the relationship between linguistic form and action formation (Curl \& Drew, 2008; Heritage, 2012; Levinson, 2013). Importantly, previous studies on English have suggested that a question format generally mitigates 
criticism, as it may give hints to the right answer in e.g. classroom interaction (Koshik, 2005). Along the same vein, questions have been seen as indirect, thus more polite devices of accomplishing face-threatening acts (Brown \& Levinson, (1987 [1978]), working on English and Tzeltal (1987[1978], pp. 223-225). On the other hand, the Anglo-centric connection between indirectness and politeness has been challenged (see e.g. Wierzbicka, 2006 for a critique of this bias), and some questions have also been claimed to have a shaming quality in Kaluli (Schieffelin, 1990). With the help of the Estonian kes-interrogative analysis, we hope to have shown that "rhetorical” questions are not necessarily polite. On the contrary, they are imposing and shaming, and reinforce a social hierarchy.

In our tape- and video-recorded data we found the breach-noticing usage of kesinterrogatives in asymmetric participant constellations, such as between teachers and students, parents and children, pet owners and pets. By uttering a kes-interrogative, the speaker defines the recipient as having made a breach and the asker as having legitimate rights to pass judgment on it. Through the formulation of action, the speaker reveals her own stance on what is expected and appropriate in the current situation, calling the addressee(s) to respect the social, moral or aesthetic norms of the activity. This may involve matters ranging from sleeping in a disgraceful manner to the morality of a promise to the aesthetic features of a dance. By way of comparison, warum 'why'-questions in German have been shown to function as reproaches and devices for moralizing (Günthner, 1996, 2000). A noticing kesinterrogative is thus essentially a claim to authority, which may be enhanced by the simultaneous embodied conduct of the speaker. She can, for example, invade the physical space of the addressee (as in the mother-son excerpt), or remain an immobile observer while others are practicing a dance move (as the teacher does in the dance classes). 


\section{Conclusion}

Interrogatives involving kes 'who', mis 'what', mida 'what:PRT', miks 'why', kus/kuhu 'where(to)', kuidas 'how', etc. may all be used for noticing breaches, calling for a remedy of the conduct and thereby reinforcing social norms. Each of the grammatical formats displays distinct nuances in their formulation of actions, with the informational focus being either on the problematic conduct itself, a missing action, wrong move, or the actor. The different formats also enable partly different responses, such as stopping the formulated action, remedying the breach, providing an account, or contesting the blame. Our target format, the kes-interrogative, ascribes responsibility to the often explicitly addressed recipient and calls for a remedy of the formulated problematic conduct.

By looking closely at the interactional use of kes-interrogatives, along with other nonpolar interrogatives, this paper argued that they are used for noticings based on the embodied conduct of others. Accordingly, they build multimodal sequences: another's conduct occasions a noticing, followed by either an embodied remedy or a verbal response by the same other. We have thus discussed a case of action formation in embodied interaction.

By focusing on the ability of kes-interrogatives to ascribe responsibility, we showed that meaning and function cannot entirely be tied to the components of the utterance but emerge in a holistic manner in sequential, turn-constructional, and embodied contexts. Function is always a combination of composition and position, as famously put by Schegloff (2007, p. xiv). Having identified a distinct, and perhaps language-specific, function of kesinterrogatives in reaction to embodied conduct, we would like to underscore that all grammatical formats should be analyzed in their culturally embedded activity contexts in order to reveal their systematic function and potentially surprising moral doings. 


\section{References}

Bolden, G., \& Robinson, J. D. (2011). Soliciting accounts with why-interrogatives in conversation. Journal of Communication, 61(1), 94-119.

Bolinger, D. (1957). Interrogative structures of American English. Publications of the American Dialect Society, 28, Ala: University of Alabama Press.

Brown, P., \& Levinson, S. (1987) [1978]. Politeness. Some universals in language usage. Cambridge, UK: Cambridge University Press.

Butler, C.W., Danby, S., \& Emmison, M. (2011). Address terms in turn beginnings: Managing disalignment and disaffiliation in telephone counselling. Research on Language and Social Interaction, 44(4), 338-358.

Clayman, S. E. \& Heritage, J. (2002). The News Interview: Journalist and Public Figures on the Air. Cambridge: Cambridge University Press.

Clayman, S. E. (2010). Address terms in the service of other actions: The case of news interview discourse. Discourse and Communication, 4(2),1-22.

Clayman, S. E. (2013). Agency in response: The role of prefatory address terms. Journal of Pragmatics, 57, 290-302.

Couper-Kuhlen, E. \& Selting, M. (2001). Introduction. In E. Couper-Kuhlen E \& M. Selting (Eds.), Studies in Interactional Linguistics. (pp. 1-22). Amsterdam; Philadelphia, PA: John Benjamins Publishing Company.

Couper-Kuhlen, E. \& Etelämäki, M. (2015). Nominated actions and their targeted agents in Finnish conversational directives. Journal of Pragmatics, 78, 7-24.

Curl, T. S., \& Drew, P. (2008). Contingency and action: A comparison of two forms of requesting. Research on Language and Social Interaction, 41(2), 129-153. 
Egbert, M. \& Vöge, M. (2008). Wh- interrogative formats used for questioning and beyond:

German warum (why) and wieso (why) and English why. Discourse Studies, 10, $17-36$.

Erelt, M., Kasik, R., Metslang, H., Rajandi, H., Ross, K., Saari, H., ... Vare, S. (1993). Eesti keele grammatika II [Estonian grammar II]. Tallinn, Estonia: Eesti Teaduste Akadeemia Eesti Keele Instituut.

Enfield, N. J., Stivers, T., \& Levinson, S. C. (2010). Question-response sequences in conversation across ten languages: An introduction. Journal of Pragmatics, 42(10), 2615-2619.

Ervin-Tripp, S. (1976). 'Is Sybil there? the structure of some American English directives’. Language in Society, 5, 25-66.

Ervin-Tripp, S. M. (1981). Social process in first and second language learning. In H. Winitz (Ed.), Native language and foreign language acquisition (Annals of the New York Academy of Science (Vol. 379)) pp. 33-47. New York, NY: New York Academy of Science.

Freed, A. F., \& Ehrlich, S. (Eds.) (2010). “Why Do You Ask?”: The Function of Questions in Institutional Discourse. Oxford, NY: Oxford University Press.

Günthner, S. (1996). The prosodic contextualization of moral work: An analysis of reproaches in 'why'-formats. In E. Couper-Kuhlen \& M. Selting (Eds.), Prosody in Conversation (pp. 271-302). Cambridge, UK: Cambridge University Press.

Günthner, S. (2000). Vorwurfsaktivitäten in der Alltagsinteraktion: Grammatische, prosodische, rhetorisch-stilistische und interaktive Verfahren bei der Konstitution kommunikativer Muster und Gattungen. Tübingen, Germany: Max Niemeyer Verlag. 
Hakulinen, A. \& Keevallik, L. (2016). Suomen ja viron kyl(lä)/küll ja kieltolausen sanajärjestys. [Finnish and Estonian $k y l(l a ̈) / k u ̈ l l$ and the word order of negative clauses.] Lähivõrdlusi. Lähivertailuja, 26, 84-126.

Heinemann, T. (2006). ‘Will you or can’t you?’: Displaying entitlement in interrogative requests. Journal of Pragmatics, 38, 1081-1104.

Hepburn, A. \& Potter, J. (2011). Threats: Power, family mealtimes and social influence. British Journal of Psychology, 50, 99-120.

Heritage, J. (2012). Epistemics in action: Action formation and territories of knowledge. Research on Language and Social Interaction 45(1), 1-29.

Keevallik, L. (2003). Colloquial Estonian. In M. Erelt (Ed.). Estonian Language (pp. 342378). Tallinn, Estonia: Estonian Academy Publishers.

Keevallik, L. (2011). Interrogative "complements" and question design in Estonian. In R. Laury \& R. Suzuki (Eds.), Subordination in Conversation: A Cross-Linguistic Perspective (pp. 37-68). Amsterdam, the Netherlands: John Benjamins.

Keevallik, L. (2012). Compromising progressivity: 'no'-prefacing in Estonian. Pragmatics, 22(1), 119-146.

Keevallik, L. (2015). Coordinating the temporalities of talk and dance. In A. Deppermann \& S. Günthner (Eds.), Temporality in Interaction (pp. 309-336). Amsterdam, the Netherlands: John Benjamins.

Keisanen, T. (2007). Stancetaking as an interactional activity: challenging the prior speaker. In R. Englebretson (Ed.), Stancetaking in Discourse: Subjectivity, Evaluation, Interaction (pp. 253-281). Amsterdam, the Netherlands: John Benjamins.

Keisanen, T. (2012). "Uh-oh, we were going there”: Environmentally occasioned noticings of trouble in in-car interaction. Semiotica, 191, 199-224. 
Koshik, I. (2005). Beyond Rhetorical Questions. Assertive Questions in Everyday Interaction. Amsterdam, the Netherlands: John Benjamins Publishing Company.

Laanesoo, K. (2012). Pööratud polaarsusega retoorilised küsimused argivestluses. [Reversed polarity questions in Estonian everyday conversation]. Keel ja Kirjandus, 7, 499-517.

Laanesoo, K. (2014). Direktiivsed mis- ja mida-küsilaused suulises suhtluses. [Directive what-interrogatives in Estonian spoken interaction]. Emakeele Seltsi Aastaraamat, 59, 103-126.

Laanesoo, K. (2017). Miks-küsilausetega läbiviidavad suhtlustegevused telefonivestlustes. [Social actions accomplished by why-interrogatives in Estonian phone conversations]. Eesti Rakenduslingvistika Aastaraamat. Lerner, G. (2003). Selecting next speaker: The context sensitive operation of a context-free organization. Language in Society, 32, 177-201.

Levinson, S. (2013). Action formation and ascription. In T. Stivers, \& J. Sidnell (Eds.), The handbook of conversation analysis (pp. 103-130). Malden, MA: WileyBlackwell.

Linell, P. (2009). Rethinking language, mind, and world dialogically: Interactional and contextual theories of human sense-making. Charlotte, NC: Information Age Publishing.

Macbeth, D. (2004). The relevance of repair for classroom correction. Language in Society, 33, 703-736.

Metslang, H. (1980). Küsilause eesti keeles. [Interrogative in Estonian]. Eesti NSV Teaduste Akadeemia Keele ja Kirjanduse Instituut. Tallinn, Estonia: Valgus.

Monzoni, C. M. (2008). Introducing direct complaints through questions: The interactional achievement of 'pre-sequences’? Discourse Studies 10(1), 73-87. 
Pajusalu, R. (1997). Is there an article in (spoken) Estonian? In M. Erelt (Ed.), Estonian typological studies II (pp. 146-177). Tartu, Estonia: Tartu ülikooli kirjastus.

Pajusalu, R., \& Pajusalu, K. (2004). The Conditional in everyday Estonian: Its form and functions. Linguistica Uralica, 4, 257-269.

De Ruiter, J. P. (Ed.), (2012). Questions: formal, functional, and interactional perspectives. Cambridge, UK: Cambridge University Press.

Sacks, H. (1992). Lectures on conversation. Oxford, UK: Blackwell.

Schegloff, E. A. (1984). On some questions and ambiguities in conversation. In J. M. Atkinson \& J. Heritage (Eds.), Structures of social action: Studies in conversation analysis (pp. 28-52). Cambridge UK: Cambridge University Press.

Schegloff, E. A. (1988). Goffman and the analysis of conversation. In P. Drew, \& A. J. Wootton (Eds.), Erving Goffman: Exploring the Interaction Order (pp. 9-135). Cambridge, UK: Polity Press.

Schegloff, E. A. (2007). Sequence Organization in Interaction: A primer in conversation analysis. Cambridge: Cambridge University Press.

Schieffelin, B. B. (1990). The Give and Take of Everyday Life: Language Socialization of Kaluli Children. New York, NY: Cambridge University Press.

Searle, J. R. (1969). Speech acts: An essay in the philosophy of language. Cambridge, UK Cambridge University Press.

Searle, J. R. (1976) A classification of illocutionary acts. Language in Society, 5, 1-23. Searle, J. R. (1979). Expression and meaning: Studies in the theory of speech acts. Cambridge, England: Cambridge University Press.

Sidnell, J. (2010). Conversation Analysis: An Introduction. Chichester, UK: WileyBlackwell. 
Sterponi, L. (2003). Account episodes in family discourse: The making of morality in everyday interaction. Discourse Studies, 5(1), 79-100.

Stivers, T., \& Rossano, F. (2010a). Mobilizing response. Research on Language and Social Interaction, 43(1), 3-31.

Stivers, T., \& Rossano, F. (2010b) A scalar view of response relevance. Research on Language and Social Interaction, 43(1), 49-56.

Tannen, D. (2007). Talking the dog: Framing pets as interactional resources in family discourse. In D. Tannen, S. Kendall, \& C. Gordon (Eds.), Family Talk: Discourse and Identity in Four American Families (pp. 49-69). New York, NY: Oxford University Press.

Weeks, P. (1996). A rehearsal of a Beethoven passage: An analysis of correction talk. Research on Language and Social Interaction, 29, 247-290.

Wierzbicka, A. (2006). Anglo scripts against "putting pressure" on other people and their linguistic manifestations. In C. Goddard (Ed.), Ethnopragmatics: Understanding discourse in cultural context (pp. 31-63). Berlin, Germany: Mouton de Gruyter. 


\section{Appendix}

\section{Transcription and Glossing Conventions}

underlining emphasis

falling intonation at the end of the intonation unit

non-final intonation at the end of the intonation unit

? rising intonation at the end of the intonation unit

(.) micropause

(1.2) pause length in seconds and tenths

:: $\quad$ prolongation of a sound

word emphasis

do- $\quad$ cut off

.hhh audible in-breath

hh audible breath

$=\quad$ latching (no silence between two items)

[ begin of overlap

] end of overlap

$<$ text $>\quad$ slower talk

$>$ text $<\quad$ faster talk

* text $* \quad$ lowered volume

CAPS loud volume

@ text@ change of tone

\$ text \$ laughing voice

hehe laughter

((text)) transcriber's comment, description

\{text $\quad$ item in doubt 
\{--- $\quad$ inaudible speech

$+\quad+\quad$ delimit descriptions of one speaker's actions

a a delimit descriptions of another's speakers actions

$--->+\quad$ action described continues until the same symbol is reached

\# the exact moment at which the figure has been taken

ADE adessive

ASP aspect marker

1, 2, 3 person

COM comitative

COND conditional

ILL illative

IMF imperfect

NEG negation

PART particle

PL plural

PPC past participle

PRT partitive

QUES question particle

SG singular 